\title{
Research on the Realistic Gap of the Supply Side of Vocational Education Talents Cultivation under the Visual Threshold of "Craftsmanship Spirit"
}

\author{
Bingbing $\mathrm{Wu}$
}

\author{
Liaoning Equipment Manufacturing Vocational and Technical College, Shenyang 110161, China;
}

Keywords: craftsmanship spirit; talent cultivation; supply-side reality gap; higher vocational education; professionalism

\begin{abstract}
Vocational education is to enable students to acquire vocational skills, vocational knowledge and an educational activity that forms a good professional spirit, it has the role that ordinary education cannot replace, it is fundamentally aimed at cultivating the needs of the country's economic development, high-quality laborers who need to adapt to the needs of production and service. "Craftsmanship spirit" comes from vocational education; it is an important part of the training of vocational education talents cultivation, and also the spiritual goal of vocational skill-oriented talents. The stage of higher vocational education is the key period for students to recognize, understand and master the spirit of craftsmanship. Vocational colleges should integrate the "craftsmanship spirit" into the whole process of personnel training, and take measures to improve the pertinence and effectiveness of talents cultivation. In the key stage of comprehensively promoting reform and innovation and upgrading the core competitiveness of the country, based on the visual threshold of "craftsmanship spirit", finding out the realistic gap in the supply side of talent cultivation can improve the quality of talents cultivation, and establish and improve the modern vocational education system. Meet the needs of economic and social development, promote the successful development of students' careers, and comprehensively enhance the attractiveness of vocational education.
\end{abstract}

\section{The Far-reaching Implications of the Supply Side of Talent Cultivation under the Visual Threshold of Craftsmen Spirit}

"Craftsmanship spirit" is a spiritual concept of pursuing the ultimate and perfection. It belongs to the category of professional attitude and professional spirit education, and is closely linked with the practitioners' outlook on life and values. Recently, the Ministry of Human Resources and Social Security officially issued the Technical Regulations for the Preparation of National Vocational Skills Standards (2018 edition). Compared with the 2012 edition of the Regulations, this regulation emphasizes the cultivation of craftsmanship and integrates the spirit of craftsmanship and professionalism into the National vocational skill standards, as an important part of professional ethics requirements.

Emphasizing the cultivation and inheritance of craftsmanship is a valuable experience of international manufacturing powers such as Germany and Japan. During the 2016 National Conference, Premier Li Keqiang stated in the government work report: "Encourage enterprises to carry out personalized customization, flexible production, and foster "craftsmanship spirit" striving for excellence, increasing varieties, improving quality, creating brands, reflects China's emphasis on the spirit of craftsmen ${ }^{[1]}$.In the work points of the Professional Capacity Building Division in 2018, it also pointed out that it is necessary to create a good social atmosphere of "big country craftsmen", and actively carry out the evaluation of the welfare of skilled workers, improve the evaluation system of skilled talents, and vigorously develop the education of technicians in the whole society. And promote propaganda work such as craftsmanship. As a high-skilled talents training base, vocational colleges must keep up with the development needs of the times, and infiltrate the students' "craftsmanship spirit" in the vocational education stage to meet the requirements of the society for high-skilled talents. 


\section{The Realistic Gap of Full-time Academic Education under the Visual Threshold of "Craftsmanship Spirit"}

From the perspective of the cultivation of craftsmanship in vocational education, $53 \%$ of vocational colleges have begun to explore the cultivation of "craftsmanship spirit", and infiltrated in professional teaching. However, the society's satisfaction with the cultivation of professional "craftsmanship spirit" is still relatively low, only $32 \%$ said that it is very satisfied and satisfied; $68 \%$ of the respondents believe that the most lacking of vocational college graduates is professionalism ${ }^{[2]}$.This shows that vocational colleges and employers have a more unified understanding of the connotation and importance of craftsmanship, but the cultivation of craftsmanship in vocational education can not meet the needs of high-skilled talents in social development. There are still some gaps in the concept of education, the education of system, the mechanism for further education, the training mechanism for personnel, and the construction of the teaching staff. The main performances are as follows:

\subsection{There is a gap in the concept of education}

Before the country vigorously advocated the "craftsmanship spirit", most parents and most students were biased in their understanding of vocational education. Most of them were due to low scores and not be admitted into undergraduate colleges to accept vocational education. The idea that vocational education is second-rate education is deeply rooted in the minds of many teachers, parents and students. In the "Evaluation Report on the Implementation of the National Financial Aid Policy for Secondary Vocational Education", students in secondary vocational schools generally feel that they cannot establish a correct outlook on career development, and career choices are easily overlooked. The reason is that the social recognition of vocational education is not high. In the early 2018s, the country introduced a number of relevant policies for vocational colleges, in order to lead the public to change the concept of education. According to relevant statistics, among the graduates of vocational colleges, the employment rate of secondary vocational schools is over 95\%, and the employment rate of higher vocational education is over 90\%.This is enough to show that the lack of professional skills talent has become the focus of attention. In the future vocational education will assume the important task of the country to train "big country craftsmen", and the professional recognition of vocational college students will also increase.

\subsection{The gap in the design of the education system}

There are great defects in the design of vocational education system in China. First of all, the setting of the entire education system is not considered to be combined with the needs of the development of the local economy supply side; Secondly, in the design of higher vocational education system, lifelong education is not considered. The three-year study only focuses on cultivating people's basic skills, and does not consider the later capacity enhancement and comprehensive development; finally, the professional setting in vocational education does not have a dynamic adjustment mechanism, so that the cultivated talents do not meet the needs of economic and social development. In the Soviet education, a vocational education system was established to vigorously develop vocational education, and Germany has infiltrated vocational education into lifelong education ${ }^{[3]}$.After experiencing a series of problems such as "labor shortage" and "missing talents", China has also paid more and more attention to the development of vocational education. The State Council issued the "Decision on Accelerating the Development of Modern Vocational Education" (Guo Fa [2014] No. 19) and the Ministry of Education and other six departments issued the "Procedures for the Promotion of School-Enterprise Cooperation in Vocational Schools" (Faculty [2018] No. 1), The Ministry of Education issued the "Opinions on Deepening the Promotion of Vocational Education Group Management" (Faculty [2015] No. 4) and the "Implementation Opinions on Promoting the Supply-side Structural Reform of High and Secondary Schools" issued by various provinces and municipalities, with a view to improving various systems of vocational education.

\subsection{The gap in the mechanism of further education}

The opening-up mechanism of higher vocational education in China is poor, and most of the students entering the vocational education system cannot enter the higher level. Even if he can apply for higher education to continue his studies, there are still many limitations in the choice of institutions, professional 
changes, and credit replacement. German elementary school students can choose to go to school after graduating from elementary school. Students with excellent grades can continue to study at Arts and Science Middle School and then enter university. The vast majority of students choose secondary schools in the direction of vocational education. They can graduate from high school and then go through vocational training for employment or enter the University of Applied Sciences for further study. Students enrolled in the University of Applied Sciences can also obtain a master's degree or a doctoral degree in higher education. In Germany, technicians who have not received higher education will not be paid less than the national average wage. After work, it is very easy to continue to study at the University of Applied Sciences. After obtaining a diploma, he can become an "engineer" from a "technician". This is still very difficult to realize in China's current education system. Although many vocational colleges implement the secondary vocational-high-undergraduate continuous learning process, but only for the students in the school, for the technical workers of the enterprise, there are not many opportunities for further education through higher education.

\subsection{The gap in the concept of "craftsmanship spirit" in the concept of talent training}

The concept of vocational education of talents cultivation in China has gradually improved with the development of social economy. It has begun to separate from traditional classroom teaching and pays attention to cultivating students' professional skills and vocational skills. However, there is a lack of pursuit and persistence in vocational and technical skills in the spirit of craftsmanship. In fact, this has deviated from the essence of vocational education. In China's vocational education, no matter which major is in school, most of the time is receiving professional teaching and professional skills training, and does not infiltrate the cultivation of "craftsmanship spirit" into the curriculum system. The introduction of "craftsmanship spirit" into vocational education is not a slogan, but the integration of craftsmanship into the talents cultivation program, and the "craftsmanship spirit" into the teaching practice of each course ${ }^{[4]}$.

\subsection{The gap in the construction of the teaching staff in the "craftsmanship spirit"}

The level of teachers determines the quality of teaching. The ancestors of our country pay great attention to the cultivation of "craftsmanship spirit". Zhang Heng and Lu Ban are the shining examples of the most "craftsmanship spirit" in Chinese history. However, most of the teachers in vocational colleges are mainly graduates of postgraduate studies. Since they graduated to higher vocational colleges as teachers, they have no experience in corporate work. Therefore, their professional theoretical knowledge is firm, their practical ability is relatively weak, and the teachers themselves' "craftsmanship spirit " quality is very much in need of improvement ,so it is impossible to train students' "craftsmanship spirit" in the process of teaching. Vocational colleges in Europe and the United States attach importance to the training and promotion of teachers' skills. Teachers will conduct professional training on a regular basis and use the holiday time to upgrade their practical skills. The principal will evaluate the teacher in various forms. The most important way is to listen to the class, and to grade the teacher by evaluation. The principal is generated from the best teacher. This method effectively stimulates the teacher to improve his ability with enthusiasm and initiative ${ }^{[5]}$.Therefore, in the process of building a professional education faculty, it is necessary to enhance the comprehensive ability of teachers, especially to regularly upgrade to enterprises. In order to implement the cultivation of "craftsmanship spirit" in the teaching process, teachers should not only improve their practical skills, but also promote the "craftsmanship spirit" through their own demonstration role. The "craftsmanship spirit" is subtly emphasized through the teaching process. Planted in the professional learning of students, laid a solid foundation for the realization of "Made in China 2025".

\section{Solutions}

For the cultivation of craftsman spirit in higher vocational colleges, we must first play the guiding role of higher vocational education, so that students themselves attach importance to the spirit of craftsmanship. In addition to skill upgrading and professional quality training, the cultivation of big country craftsmen also needs to guide students to pay attention to the spirit of craftsmen in their minds 
and emotions. Only by recognizing their own identity they can play a better role in their posts and the craftsmen spirit can be truly promoted in ideology and skill,. Secondly, on the campus, the atmosphere of "big country craftsmen" is created, so that every student can work hard and be proud to become a qualified craftsman in the future. In the process of teaching, the teacher also actively infiltrates the craftsmanship spirit. Finally, the enterprise is an important position for cultivating the craftsmen of the big country craftsmen, and actively promotes the promotion of school-enterprise cooperation, so that students can feel the craftsman spirit everywhere in advance ${ }^{[6]}$.

\section{Summary}

Carrying forward the spirit of craftsmen, creating a glorious social style of work and striving for excellence of and dedicated atmosphere are the core of contemporary vocational education. Finding the realistic gap in the supply side of vocational education talents cultivation under the visual threshold of craftsmanship spirit, it can help to improve the level of vocational education and improve the quality of talents cultivation.

\section{Acknowledgement}

The Project of the 2017 Annual Artisan Spirit and Talent Cultivation Special Fund of Liaoning Radio and Television University (Project No.: 2017HBGRZ-06).

\section{References}

[1]. Li Keqiang. 2016 National Work Report of the National People's Congress [R]. Beijing: Central People's Government of the People's Republic of China, 2016.In Chinese

[2]. Tao Wenhui, Ma Guixiang. Research on the Cultivation Practice of Vocational Education Talents Based on the Spirit of Craftsman[J]. Vocational Education Forum, 2017(2): 63-64.In Chinese

[3]. Feng Wei. Reference and Reflection on the Development of Adult Non-degree Education in Germany[J]. Continuing Education Research, 2016(11): 105-107.In Chinese

[4]. Shi Bo. Innovation of the training mechanism of higher vocational talents under the vision of "artisan spirit"[J].Journal of Qingyuan Vocational and Technical College,2016(7):70-73.In Chinese

[5]. Wang Qianwen. Germany: "Artisan spirit" training into the whole process of teaching [N]. "China Education News" June 06, 2017 12th edition name: Vocational Education Weekly·Frontier topics. In Chinese

[6]. Xiao Bo, Xiao Xia. Cultivation of Craftsmanship of Higher Vocational Students under the Perspective of Integration of Production and Education[J].Education and occupation, 2018 (14): 109-112.In Chinese 